Brit. J. industr. Med., 1957, 14, 56

\title{
DELAYED DEATH CAUSED BY GASSING IN A SILO CONTAINING GREEN FORAGE
}

\author{
BY \\ F. M. TROISI \\ From the Medical Clinic, University of Bologna, Italy
}

(RECEIVED FOR PUBLICATION SEPTEMBER 11, 1956)

Three workers died from carbon dioxide poisoning in a partly underground silo which had been almost completely emptied of green forage. Two died at once, the third after five days without regaining consciousness.

Several similar cases are reported in the literature. Wrede (1936) described a case of carbon dioxide poisoning which occurred in a cellar through the escape of gas from a beer barrel. The patient, seen four minutes after he had been removed from the cellar, was unconscious but recovered in a few minutes. The clinical picture was one of narcosis followed by excitation and could easily have been mistaken for drunkenness or epilepsy.

Bernauer and Blume (1937) reported the cases of three Chinese employees working in the hold of a ship in Canton port who were poisoned by carbon dioxide produced by the fermentation of rice and soya. One of them died at once, the second recovered quickly, and the third succumbed after four days without regaining consciousness.

Taeger (1937) reported the case of a youth of 22, who collapsed in a silo containing green forage. When removed from the silo he was completely unconscious, the pupils dilated and reacting feebly to light, and Cheyne-Stokes respiration was present. After 20 hours he began to improve slowly. Acrocyanosis then appeared in the hands and feet which was still present two years after the incident and was considered by the author to be aetiologically connected with the attack of carbon dioxide poisoning.

Symanski (1939) described four workers who lost consciousness in a silo containing green forage but recovered. One had aphasia for a short time after recovering consciousness, and in one case seen a week after the incident there was marked acrocyanosis of the hands.

\section{Case Report}

On May 20, 1954, a youth of 18 and a boy of 12 descended into a silo on a small farm. The silo was con- structed of cement, cylindrical in shape, 6 metres high and about 4.5 metres in diameter, about half its height being buried in the ground, with only one opening in the roof, which was closed with a metallic cover. Green forage, mixed with beans, barley, and oats had been preserved in the silo, which had been nearly empty for about a month, with the cover in place. The two youths entered the silo to remove the remaining silage before replacing it with fresh material. Shortly after reaching the bottom of the silo they collapsed and became unconscious. A man of 61 standing nearby went into the silo to help them and he also lost consciousness. All three were dragged out with grappling hooks and artificial respiration was applied. The two youths were already dead. The elderly man was immediately taken to the nearest clinic. He appeared to be in extremis; the only sign of life was intermittent cardiac contractions. Artificial respiration was started at once and cardiac and respiratory stimulants were given together with $500 \mathrm{ml}$. plasma intravenously. After about an hour a few spontaneous respirations began and progressively in about 10 minutes tachypnoea developed. Consciousness was not regained at any time.

After five hours he was admitted to hospital completely unconscious, the superficial and deep reflexes, pupillary and corneal reflexes absent, a positive Babinski sign, more marked on the left side, double incontinence, tachycardia (120/min.) and tachypnoea (blood pressure $70 / 55 \mathrm{~mm} . \mathrm{Hg}$ ), and a temperature of $97 \cdot 9^{\circ} \mathrm{F}$. Lobeline and oxygen were administered, and a transfusion of $300 \mathrm{ml}$. of blood was given, preceded by bleeding; antibiotics were given prophylactically. In the first 15 hours the tachypnoea ceased but violent generalized convulsions recurred at half-hourly intervals. Four transfusions of $300 \mathrm{ml}$. of blood, preceded by bleeding, were given during the ensuing 24 hours and the blood pressure increased to $120 / 75 \mathrm{~mm}$. $\mathrm{Hg}$ but fell again after a short time. The temperature rose to $100 \cdot 4^{\circ} \mathrm{F}$. Oxygen and antibiotics were given. Towards the end of the second and the beginning of the third day a partial but shortlived recovery of the abdominal and lower limb reflexes took place. On the afternoon of the second day the blood was examined chemically and spectroscopically; no carbon monoxide was present. On the third day the condition remained unchanged (blood pressure $85 / 60 \mathrm{~mm}$. 
$\mathrm{Hg}$, temperature $101 \cdot 3 \mathrm{~F}$.) and a blood transfusion was given without previous bleeding as the pulse pressure was very low, together with oxygen and antibiotics. On the fourth day the clinical picture was similar (blood pressure $90 / 75 \mathrm{~mm}$. $\mathrm{Hg}$, temperature $102 \cdot 2^{\circ} \mathrm{F}$.), and treatment was given as on the previous day. On the fifth day, May 25 , the temperature rose to $102 \cdot 6^{\circ} \mathrm{F}$. and finally to about $104^{\circ} \mathrm{F}$. just before death. Throughout the illness there was complete loss of consciousness; all urine tests showed albumin; the non-protein nitrogen level in the blood in the first 24 hours was $52 \mathrm{mg} . \%$, rising to $75 \mathrm{mg}$. \% on the fourth day. From his friends it was ascertained that the patient had previously enjoyed good health and they could not remember any illnesses from which he had suffered.

The clinical picture was that of asphyxia, which did not cause death immediately, either because the length of time during which the patient remained in an atmosphere of complete anoxia was very short (less than eight minutes, a duration which is generally admitted to be quickly fatal), or perhaps because there was a reduced partial pressure of oxygen. This was a case of delayed death due to carbon dioxide intoxication and perhaps to anoxaemia also. The clinical picture was characteristic of prolonged partial anoxaemia such as occurs in cases of slowly induced asphyxia or under anaesthesia with nitrous oxide and less than $10 \%$ oxygen. In these conditions the central nervous system may be seriously damaged, and death may occur after hours or days during which respiration with pure air or oxygen proves ineffective (Henderson and Haggard, 1943).

The progressive rise in temperature, apparently not caused by any inflammatory condition, is worth noting, as similar increases in temperature were observed in the cases reported by Parade (1930) and by Bernauer and Blume (1937), which they regarded as being due to toxic effects on the thermoregulatory centre. In the incident now described, the cause of the fatal toxic effect in the three employees was evidently the carbon dioxide produced by fermentation of forage remaining in the silo, activated by the higher spring temperatures and accumulating on account of its higher density in the lower part of the closed silo. Chemical examination of a sample of forage taken from the silo revealed active fermentation; it was thought that weed killers and insecticides used in the fields might have left a residue which could have given rise to arsine or phosphine, but arsenic and phosphorus were absent from the sample. It is well known that in such conditions a high concentration of carbon dioxide may accumulate at the bottom of silos. Fermentation is determined by the nature and state of the forage (type, chemical composition, humidity, and enzyme complexes), by conditions of complete and incomplete anaerobiosis, by the initial and continuing temperatures, and by the type and amount of bacteria. Fermentation also results in the production of small quantities of hydrogen and methane.

The risk of carbon dioxide poisoning in silos, granaries, and holds of ships, where forage or grain is stored, has been known since ancient times and fatal cases continue to be reported from time to time in the daily press. Ramazzini (1713) warned that

" a fact worthy of marvel is that from grain which has been long conserved in a closed chamber, for example in underground places as is the custom in Tuscany, arises an exhalation so dangerous as to be sufficient to cause death to anyone who enters such a place to collect the grain, unless the pernicious air is first allowed to escape for a while."

It is important to remember that a very considerable accumulation of carbon dioxide may take place in silos, whether they contain forage or grain. Apart from fermentation and putrefactive processes, an increased natural respiration of the grain readily occurs as may be deduced from the following data. One kilogram of grain containing $14-15 \%$ of moisture at a temperature of $18^{\circ} \mathrm{C}$. produces $1.4 \mathrm{mg}$., at $30^{\circ} \mathrm{C} .7 .5 \mathrm{mg}$., and at $52^{\circ} \mathrm{C}$. $249 \mathrm{mg}$. of carbon dioxide in 24 hours. Again, $1 \mathrm{~kg}$. of grain at a temperature of $18^{\circ} \mathrm{C}$. produces, with a moisture content of 14 to $15 \% 1.4 \mathrm{mg}$., of $16.9 \% 123 \mathrm{mg}$., and of $33 \% 2,000 \mathrm{mg}$. of carbon dioxide in 24 hours (Bordewieck, 1936).

The type of silo described above, half-buried in the ground and with a single opening in the roof, should be prohibited; in addition all silos should be provided with a free opening at the base. Underground tanks and vats must be actively ventilated before they are entered, and the person entering such a chamber must be secured by a rope and be observed from outside. When it is necessary to enter a chamber where the presence of carbon dioxide is known or suspected, it is essential to use breathing apparatus which draws air from outside the chamber, or self-contained breathing apparatus. Other preventive measures to be adopted depend on the conditions under which the work is undertaken; it is important to give adequate instruction to the employees on the nature of the danger and its prevention. Posters may be displayed at farms indicating the dangers and the necessary preventive measures.

Methods used for testing enclosed atmospheres for the presence of carbon dioxide and of sufficient oxygen are to lower lighted candles or small caged animals into the chamber, and these are fairly reliable rough tests of safety. Parade (1930), however, besides noting differences in individual susceptibility to carbon dioxide poisoning, warned that 
warm-blooded experimental animals may only become unconscious at an atmospheric concentration of carbon dioxide as high as 25 to $30 \%$ and that it is therefore not sufficient to place rats, mice, or similar animals in small cages in the suspected atmosphere. In dogs, cats, rats, and mice a concentration of $10 \%$ of carbon dioxide in inspired air may have no observable effect but in man a similar concentration may be dangerous to life (Symanski, 1939). For this reason animals are reliable indicators only in a medium in which the partial pressure of oxygen is much reduced or absent. The candle test was indicated by Pliny the Elder, who says "Ergo vini faeci tanta vis est ut descendentes in cupas enecet. Experimentum demissa praebet lucerna, quamdiu extinguatur, periculum denuntians", thus recommending, as a precaution against fatal poisoning due to entering a wine vat, the lowering of a lighted candle into the vat and ascertaining the danger from the extinction of the flame. This type of test may be used quantitatively, as, at a concentration of $2 \%$ of carbon dioxide a candle flame assumes a reddish light, at 8 to $10 \%$ candles and oil lamps are extinguished, and at 12 to $14 \%$ alcohol lamps are extinguished but acetylene lamps are not extin- guished until a concentration of 30 to $31 \%$ is reached (Holstein, 1949). There are, of course, numerous ways of estimating by physical or chemical methods the concentration of carbon dioxide in a working atmosphere.

\section{Summary}

Three fatal cases of carbon dioxide poisoning occurred in a half-underground silo nearly emptied of green forage.

One case, in which death occurred five days after the gassing incident, is described in detail.

The toxicology of carbon dioxide and its estimation in working environments are discussed and preventive measures described.

\section{REFERENCES}

Bernauer, E., and Blume, W. (1937). Samml Vergifiungsf., 8, A 191. Bordewieck, H. (1936). Ibid., 7, A 57 .

Henderson, Y., and Haggard, H.' W. (1943). Noxious Gases, 2nd ed. p. 142. Reinhold Publishing Corporation, New York.

Holstein. E. (1949). Grundriss der Arbeitsmedizin, p. 136. Barth, Leipzig.

Parade, G. W.(1930). Samml. Vergiftungsf., 1, A 171

Plinius Secundus, C. Historia Naturalis., Frellonium, Lugduni, Lib. 23, C. II, p. 431. (1553.)

Ramazzini, B. (1713) De Morbis Artificum Diatriba, Conzatto, Padova, Cap. XXIII.

Symanski, H. (1939). Gasmaske, 11, 19.

Taeger, H. (1937). Samml. Vergiftungsf., 8, в 19.

Wrede, F. (1936). Ibid., 7, A 49. 